\title{
Optic coherence tomography measurement of choroidal and retinal thicknesses after uncomplicated YAG laser capsulotomy
}

\author{
Medidas das espessuras de coroide e retina após capsulotomia por YAG laser não complicada \\ İsa Yuvaci ${ }^{1}$, Emine Pangal ${ }^{1}$, Yudum Yüce ${ }^{1}$, Sümeyra Yuvaci ${ }^{1}$, Nurettin Bayram ${ }^{1}$, Döndü Melek Ulusoy ${ }^{1}$, Ali Akal ${ }^{2}$, Orhan Altunel ${ }^{1}$
}

\begin{abstract}
Purpose: Optic coherence tomography (OCT) evaluation of the choroid, retina, and retinal nerve fiber layer after uncomplicated yttrium-aluminum-garnet (YAG) laser capsulotomy.

Methods: OCT analysis of retinal and choroidal structures was performed in 28 eyes of 28 patients following routine examinations before and 24 h, 72 h, 2 weeks, 4 weeks, and 12 weeks after YAG laser capsulotomy. Data were analyzed using the SPSS software.

Results: Data collected before YAG capsulotomy and at the above mentioned follow-up visits are summarized as follows. Mean central subfoveal choroidal thickness before YAG capsulotomy was $275.85 \pm 74.78 \mu \mathrm{m}$; it was $278.46 \pm$ $83.46 \mu \mathrm{m}, 283.39 \pm 82.84 \mu \mathrm{m}, 280.00 \pm 77.16 \mu \mathrm{m}, 278.37 \pm 76.95 \mu \mathrm{m}$, and $278.67 \pm$ $76.20 \mu \mathrm{m}$ after YAG capsulotomy, respectively. Central macular thickness was $272.14 \pm 25.76 \mu \mathrm{m}$ before YAG capsulotomy; it was $266.53 \pm 26.47 \mu \mathrm{m}, 269.14 \pm$ $27.20 \mu \mathrm{m}, 272.17 \pm 26.97 \mu \mathrm{m}, 270.91 \pm 26.79 \mu \mathrm{m}$, and $273 \pm 26.63 \mu \mathrm{m}$ after YAG capsulotomy, respectively. Mean retinal nerve fiber layer thickness before YAG was $99.89 \pm 7.61 \mu \mathrm{m}$; it was $98.50 \pm 8.62 \mu \mathrm{m}, 98.14 \pm 8.69 \mu \mathrm{m}, 99.60 \pm 8.39 \mu \mathrm{m}$, $99.60 \pm 8.39 \mu \mathrm{m}$, and $99.60 \pm 8.35 \mu \mathrm{m}$ after YAG capsulotomy, respectively. No observed change was statistically significant. No significant changes were observed with regard to mean intraocular pressure.

Conclusions: After YAG laser capsulotomy, no statistically significant changes were found in choroidal, retinal, and optical nerve fiber layer thicknesses, although slight thickness changes in these structures were observed, particularly during the first days.
\end{abstract}

Keywords: Choroid; Retina; Tomography, optical coherence; Posterior capsulotomy/methods

\begin{abstract}
RESUMO
Objetivo: Avaliação da coroide, retina e a camada de fibras nervosas da retina por meio de tomografia de coerência óptica (OCT) após capsulotomia por YAG laser não complicada.

Método: Vinte e oito olhos de 28 pacientes foram incluídos neste estudo. Estruturas da retina e coroide foram analisados usando ACT nos exames de rotina antes da capsulotomia posterior por YAG laser e 24 horas, 72 horas, 2 semanas, 4 semanas e 12 semanas após YAG. Os resultados foram avaliados através do programa SPSS.

Resultados: Os resultados deste estudo, pré YAG e às visitas de acompanhamento acima, podem ser resumidos da seguinte forma. A espessura média de coroide subfoveal central antes do YAG foi 275,85 $\pm 74,78 \mathrm{~m}$; após YAG foi 278,46 $\pm 83,46 \mu \mathrm{m}$, $283,39 \pm 82,84 \mu \mathrm{m}, 280,00 \pm 77,16 \mu \mathrm{m}, 278,37 \pm 76,95 \mu \mathrm{m}$, e 278,67 $\pm 76,20 \mu \mathrm{m}$, respectivamente. A espessura macular central foi $272,14 \pm 25,76 \mathrm{~mm}$ antes YAG; e 266,53 $\pm 26,47 \mu \mathrm{m}, 269,14 \pm 27,20 \mu \mathrm{m}, 272,17 \pm 26,97 \mu \mathrm{m}, 270,91 \pm 26,79 \mu \mathrm{m}$, e $273 \pm 26,63$ $\mu m$, respectivamente. Espessura média da camada de fibras nervosas da retina antes do YAG foi $99,89 \pm 7,61 \mathrm{~mm}$; e 98,50 $\pm 8,62 \mu \mathrm{m}, 98,14 \pm 8,69 \mu \mathrm{m}, 99,60 \pm 8,39 \mu \mathrm{m}$, de $99,60 \pm 8,39 \mu \mathrm{m}, 99,60 \pm 8,35 \mu \mathrm{m}$, respectivamente. Nenhuma das alterações observadas foram estatisticamente significativas. As médias da pressão intraocular, também não mostraram alterações significativas.

Conclusões: Não houve mudanças significativas foram encontradas na coroide, camada de fibras nervosas da retina espessuras e ópticos, após a capsulotomia por YAG laser, embora houvesse, especialmente nos primeiros dias, discretas alterações de espessura nas estruturas mencionadas.
\end{abstract}

Descritores: Coroide; Retina; Tomografia de coerência óptica; Capsulotomia posterior/métodos

\section{INTRODUCTION}

Despite changes in lens design and advances in surgical techniques, the development of posterior capsular opacification (PCO) is the most common complication following cataract surgery. Although various methods to treat PCO have been attempted, neodymium yttrium-aluminum-garnet (YAG) capsulotomy is yet the gold standard because it is non-invasive, can be applied rapidly under polyclinic conditions, and has a high success rate. However, some complications may occur after YAG capsulotomy ${ }^{(1-3)}$.

Changes in intraocular pressure are frequently observed following YAG capsulotomy ${ }^{(4)}$ and may have an impact on the choroid, which is sensitive to fluctuations inintraocular pressure (IOP). Furthermore, the probability of a reaction in the retina and choroid structures induced by the inflammation that may occur in the first days of the procedure should be considered. Moreover, retinal complications that may emerge later affect the choroid tissue. Various studies associated with anterior chamber and retinal changes in patients who have undergone YAG capsulotomy have been published ${ }^{(4-6)}$. However, to the best of our knowledge, there are no publications regarding choroidal change.

Therefore, we aimed to evaluate retinal and choroidal structures within the time periods when such changes are frequently observed. Potential positive findings could indicate whether optic coherence tomography (OCT) can be used for follow-up. We aimed to identify whether there were any changes at the 72-h follow-up, when inflammation after the procedure is high,and at 8-12 weeks after the procedure, when cystoid macular edema (CME) development is expected.
Submitted for publication: August 5, 2015

Accepted for publication: September 12, 2015

${ }^{1}$ Kayseri Training and Research Hospital Eye Clinic, Kayseri, Turkey.

${ }^{2}$ Department of Ophthalmology, Harran University School of Medicine, Sanliurfa, Turkey
Funding: No specific financial support was available for this study.

Disclosure of potential conflicts of interest: None of the authors have any potential conflict of interest to disclose.

Corresponding author: İsa Yuvacı. Kayseri Training and Research Hospital Eye Clinic. Hastane Str, 38010 - Kocasinan, Kayseri - Turkey -E-mail: mdisay@hotmail.com

Approved by the following research ethics committee: Erciyes University Ethics Committee 2014/356. 


\section{METHODS}

This prospective study was performed at the Ophthalmology Department of the Kayseri Education and Research Hospital. The study adhered to the tenets of the Declaration of Helsinki and was approved by the Local Ethics Committee of Erciyes University. All individuals received both oral and written information regarding the study, and each subject provided written and informed consent before participation in the study.

Patients were selected between December 2014 - March 2015, and the study involved 28 eyes of 28 patients suffering from PCO. The patients had to fulfill the following inclusion criteria: underwent cataract surgery with phacoemulsification and clinically observable PCO as observed by the slit lamp examination in only one eye; capable of being evaluated for at least 3 months after intervention by capsulotomy; and exhibited a centered intra ocular lens (IOL) with complete overlap between the anterior capsule and IOL. Patients who had glaucoma, corneal or retinal disease, uveitis, previous laser treatments, ocular trauma, or surgery during the follow-up period were excluded.

All individuals underwent a screening process involving a complete ophthalmologic examination, including refraction and visual acuity, slit-lamp biomicroscopy, intraocular pressure measured using non-contact tonometry, and fundus examination. Data on retinal nerve fiber layer (RNFL) thickness, macular thickness, macular volume, and choroidal thickness were obtained using the Spectralis OCT (Heidelberg Engineering, Heidelberg, Germany).

Image acquisition: The procedure for obtaining enhanced depth imaging (EDI)-OCT has previously been described ${ }^{(7)}$. The central subfoveal choroidal thickness (CEDI) was measured using spectral-domain OCT (Spectralis, Wave-length: 870 nm; Heidelberg Engineering Heidelberg, Germany) with the EDI modality. CEDI was defined as the vertical distance from the hyperreflective line of Bruch's membrane to the hyper-reflective line of the inner surface of the sclera. All subjects were imaged by the same experienced technician. Two independent clinicians measured CEDI, and the average of these measurements was used in the analysis. All scans were performed during the same time of the day, between 11:00-12:00, to minimize the possibility of CEDI changes attributable to diurnal CEDI fluctuations ${ }^{(8)}$. Routine examinations and OCT measurements were repeated at $24 \mathrm{~h}, 72 \mathrm{~h}$, 2 weeks, 4 weeks, and 12 weeks following the application of YAG capsulotomy.

\section{Surgical teCHNIQUe}

YAG laser capsulotomy was performed at least 3 months after surgery. Patients were treated with minimal energy and the minimal count of shots to provide sufficient capsule clarity, and a full ophthalmological examination was conducted for all patients. Pupil dilatation was provided with $1 \%$ tropicamide instillation before capsulotomy. Topical $0.5 \%$ proparacaine hydrochloride was used for corneal anesthesia. The biomicroscope was set to observe the posterior capsule after implantation of the capsulotomy lens to the eye.
Capsulotomy was performed using a Tango YAG laser system (Ellex, Adelaide, Australia). The number of laser shots and shot energy were recorded. A cross or circular technique was performed according to the surgeon's preference to obtain a capsulotomy of approximately $4 \mathrm{~mm}$. After the procedure, $5 \mathrm{mg} / \mathrm{mL}$ of prednisolone phosphate four times a day was applied to the treated eye for 2 weeks.

\section{Statistical anAlysis}

All statistical analyses were performed using SPSS for Windows version 22.0 (SPSS, Inc, Chicago, IL, USA). Continuous variables were presented as mean \pm standard deviation. Pearson's chi-square test was used to assess qualitative variables. Normal distribution was evaluated by using the Kolmogorov-Smirnov test. Homogeneity of variance was tested using Levene's test. For parametric statistics, normallydistributed data were analyzed using the repeated measures ANOVA test. When a significant result was obtained, Bonferroni's correction was used for post-hoc comparisons. A p value $<0.05$ was considered statistically significant.

\section{RESULTS}

Overall, 28 patients (13 males and 15 females) were included in the study. The mean age was $63.17 \pm 9.67$ years (age range, $42-80$ years). The mean axial length ( $\mathrm{AL}$ ) was $23.23 \pm 0.88 \mathrm{~mm}$. The mean time passed from cataract surgery to YAG capsulotomy was 47.46 \pm 16.98 months. The mean application of YAG power was $41.93 \pm$ (14-83) mj. The mean three month spherical equivalent was measured as $-0.55 \pm 1.49$ diopter (D).

As shown in table 1, while the mean IOP before YAG was 14.25 $\pm 2.74 \mathrm{mmHg}$, it was measured to $15.21 \pm 3.22 \mathrm{mmHg} 12$ weeks after YAG capsulotomy, but this difference and the other observed differences during the follow-up measurements were not found to be statistically significant. Similarly, as demonstrated in table 1 and figure 1, CEDI was $275.85 \pm 74.78 \mu \mathrm{m}$ at baseline and $278.67 \pm$ $76.20 \mu \mathrm{m} 12$ weeks after YAG capsulotomy. Changes in CEDIresults were not statistically significant $(p=0.198)$. Similarly, as shown in table 1 and figure 2, the central macular thickness (CMT) before YAG capsulotomy was $272.14 \pm 25.76 \mu \mathrm{m}$ and $273 \pm 26.63 \mu \mathrm{m} 12$ weeks after YAG capsulotomy. These findings were not statistically significant either $(p>0.05)$

Table 1 shows that the central macular volume (CMV) value was $0.2100 \pm 0.01 \mathrm{~mm}^{3}$ at baseline and $0.2139 \pm 0.001 \mathrm{~mm}^{3} 12$ weeks after YAG. Changes in CMV values were alsofound statistically insignificant $(p=0.115)$. Table 1 demonstrates a total macular volume (TMV) value of $8.53 \pm 0.33 \mathrm{~mm}^{3}$ before YAG capsulotomy and $8.54 \pm 0.34 \mathrm{~mm}^{3} 12$ weeks after YAG capsulotomy; however, again the displayed changes with regard to TMV values were statistically insignificant $(p=0.245)$.

Figure 3 and table 1 show the RNLF changes between baseline $(99.89 \pm 7.61 \mu \mathrm{m})$ and 12 weeks after YAG capsulotomy (99.60 \pm $8.35 \mu \mathrm{m})$; no statistical significance $(P=0.130)$ was observed through the follow-up.

Table 1. Most important findings observed before and after neodymium yttrium aluminum garnet capsulotomy (YAG)

\begin{tabular}{|c|c|c|c|c|c|c|}
\hline & TO mmHg & сMT $\mu$ & CEDİ $\mu$ & GnRNFL $\mu$ & CMV mm $\mathrm{mm}^{3}$ & TMV mm $^{3}$ \\
\hline BYAG & $14.25 \pm 2.74$ & $272.14 \pm 25.76$ & $275.85 \pm 74.78$ & $99.89 \pm 7.61$ & $0.2100 \pm 0.01$ & $8.53 \pm 0.33$ \\
\hline A $24 \mathrm{~h}$ & $14.32 \pm 3.07$ & $266.53 \pm 26.47$ & $278.46 \pm 83.46$ & $98.50 \pm 8.62$ & $0.2111 \pm 0.01$ & $8.52 \pm 0.32$ \\
\hline A $72 \mathrm{~h}$ & $15.03 \pm 3.21$ & $269.14 \pm 27.20$ & $283.39 \pm 82.84$ & $98.14 \pm 8.69$ & $0.2100 \pm 0.01$ & $8.52 \pm 0.33$ \\
\hline A $2 w$ & $14.82 \pm 3.07$ & $272.17 \pm 26.97$ & $280.00 \pm 77.16$ & $99.60 \pm 8.39$ & $0.2100 \pm 0.03$ & $8.53 \pm 0.33$ \\
\hline A 4 w & $15.01 \pm 3.10$ & $270.91 \pm 26.79$ & $278.37 \pm 76.95$ & $99.60 \pm 8.39$ & $0.2136 \pm 0.01$ & $8.53 \pm 0.33$ \\
\hline A 12 w & $15.21 \pm 3.22$ & $273.00 \pm 26.63$ & $278.67 \pm 76.20$ & $99.60 \pm 8.35$ & $0.2139 \pm 0.01$ & $8.54 \pm 0.34$ \\
\hline
\end{tabular}

$\mathrm{B}=$ before; $\mathrm{A}=$ after; $\mathrm{CMT}=$ central macular thickness; $\mathrm{CEDI}=$ central subfoveal EDI; GnRNFL= average retinal nerve fiber layer; $\mathrm{CMV}=$ central macular volume; TMV= total macular volume 


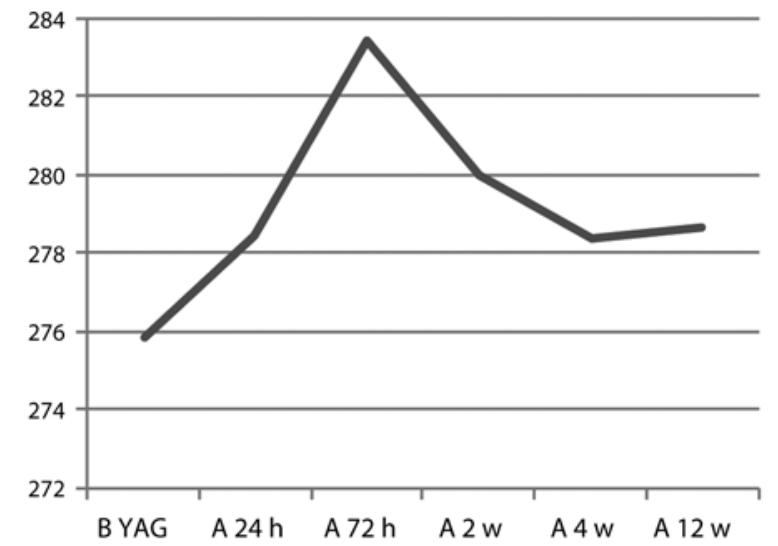

$\mathrm{CEDI}=$ central subfoveal $\mathrm{EDI} ; \mathrm{B}=$ before; $\mathrm{A}=$ after; $\mathrm{H}=$ hour; $\mathrm{W}=$ week.

Figure 1. CEDI changes over time.

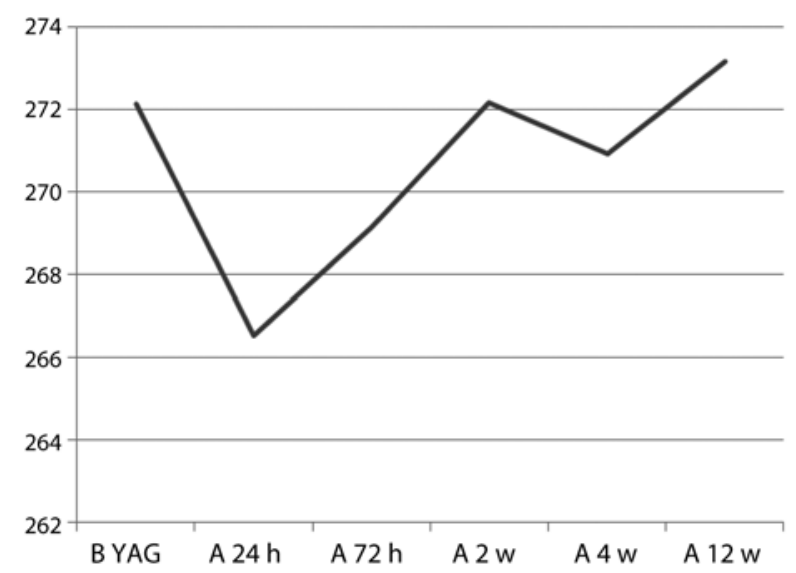

$\mathrm{CMT}=$ central macular thickness; $\mathrm{B}=$ before; $\mathrm{A}=$ after; $\mathrm{H}=$ hour; $\mathrm{W}=$ week.

Figure 2. CMT changes over time.

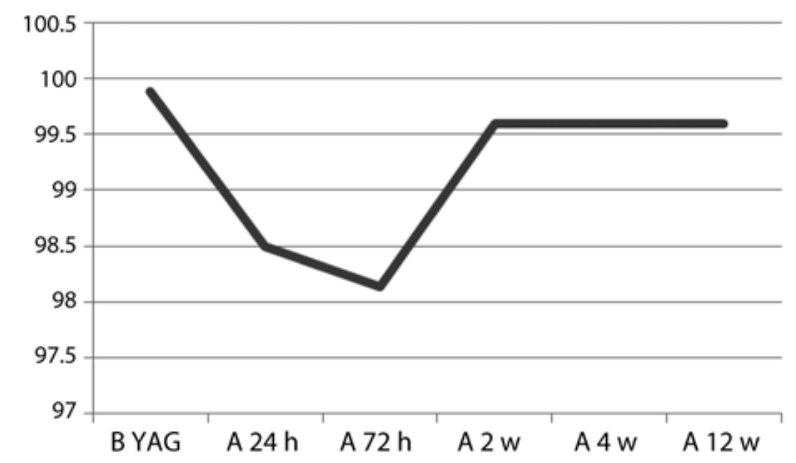

$R N F L=$ retinal nerve fiber layer; $B=$ before; $A=$ after; $H=$ hour $W=$ week.

Figure 3. RNFL changes over time.

Changes in the values of IOP, CMT, CMV, TMV, CEDI, and the general RNFL were found to be statistically insignificant as measured before and after YAG capsulotomy (Table 1).

\section{DISCUSSION}

YAG lasercapsulotomy is the standard treatment for PCO, which is seen generally between 20\%-50\% after 5 years of the surgery ${ }^{(9-11)}$. Although it is a reliable method, complications such as refraction changes, IOP changes, IOL injury, IOL dislocation, macular edema, iridocyclitis, vitritis, vitreous hemorrhage, and retinal detachment have been reported after YAG laser capsulotomy ${ }^{(2,3,12)}$.

Post-YAG capsulotomy retinal complications generally tend to be revealed later and have more risks in terms of functional loss. A previous study ${ }^{(3)}$ evaluated YAG-associated complications and found a ruptured anterior hyaloid rate of $7.5 \%$, a retinal tear rate of $4.1 \%$, a retinal detachment rate of $2.5 \%$ and a macular edema rate of $4.1 \%$. CME, in particular, which is commonly observed after surgery (observed clinically at a 1\%-level post-phaco) is the most delicate problem and may present as disturbed vision after YAG capsulotomy ${ }^{(13)}$. It is most commonly observed between 8 and 12 weeks after YAG. IOP changes, vitreous fluctuations, degradation products, and inflammation after YAG can result in disruption of the blood retinal barrier and retinal detachment ${ }^{(14,15)}$. The inflammation and damage caused by particles which were revealed besides the impact of inflammation generally made by the process can create a response in the retina. All these factors can result in increased thickness or a decrease in the thickness of posterior structures like the retina and choroid.

In one study, the authors stated that they did not detect any meaning ful increase in OCT measurements after laser capsulotomy for patients in whom the authors measured the thickness of the central macula with preoperative $O C T^{(16)}$. In our study, the measurements were repeated $24 \mathrm{~h}$ and $72 \mathrm{~h}$ after application to closely follow any potential inflammatory processes, and at the $2^{\text {nd }}$ and $4^{\text {th }}$ week after discontinuation of drug administration, and because of the possibility of disruption of the blood retinal barrier, the measurements were repeated at the $12^{\text {th }}$ week in which week CME is observed most frequently. On the first day following YAG capsulotomy, an increase was observed in CMT. This rise had a tendency to recover on the $3^{\text {rd }}$ day, and the values at week 2 , week 4 , and week 12 , were similar to those observed on the first day. No statistically significant difference was observed during all these changes. Probably, a slight vasoconstriction occurred in the retinal vessels, and by that time, because no complication had developed, there was recovery.

Cystoid macular edema was not observed in any of the $28 \mathrm{pa}-$ tients, and no statistically significant difference was observed in CME measurements in terms of macular thickness and macular volume. Similarly, a study ${ }^{(17)}$ monitoring various parameters after YAG capsulotomy in 31 eyes, reported that the change in arc macular thickness was not statistically significant. Another similarity to this study was that no complications developed over the follow-up period, which had an equal length. Therefore, this demonstrates that the follow-up of complicated cases would be more significant during the process. The reason for preferring uncomplicated cases in particular is to enable normal results to be monitored. No statistically significant change in macular thickness was observed in this study during the follow-up of 3 months. Furthermore, for this period, the procedure is found reliable for uncomplicated cases. The follow-up of 3 months may be too short for these cases.

In a study on the comparison of post-YAG capsulotomy size and macular thickness, it was stated that a rise in IOP could be related to a large capsulotomy but not a change in macular thickness ${ }^{(6)}$. Similarly, in a study performed by reviewing the applied force and complication, the authors ${ }^{(4)}$ found that CMT change was significant in cases where $>80 \mathrm{mj}$ was applied, but insignificant when a force $<80 \mathrm{mj}$ was applied. Here if we consider that the necessary dose is applied to open the capsule, this means that a higher dose results in a more rigid and thick capsule and the release of more capsular degradation products. In our study, no significant thickness or IOP change was observed. The average dose applied in our study was 40.97 (10-80) mj 
and could be considered equivalent to that applied in the group in which $<80 \mathrm{mj}$ was used. In this regard, the results of our study overlapped with that study. The long-term effect of the reactions that occur in the early days after YAG capsulotomy vary depending on the distortion of the blood retinal barrier while it recovers from inflammation; it is unlikely that they could be independent there of in the process.

The choroid, being responsible for $85 \%$ of ocular perfusion, is sensitive to IOP changes. Increased IOP following YAG is the most common complication; despite prophylactic treatment its incidence was observed as between 15\%-30\% in some studies ${ }^{(18,19)}$. The short- and long-term results are unclear in studies ${ }^{(19-21)}$ examining IOP changes after YAG capsulotomy. Whether or not the choroid is influenced as a result of pressure fluctuations after YAG capsulotomy should therefore be subject to scrutiny. Moreover, there is a possibility that the inflammation in the first days after the procedure might bring about a change in choroidal tissues. Various changes in the choroid are also probable in retinal complications (which are seen at a later stage).

For various diseases and conditions, the thickness of the choroid, which has an important role in the nutrition of the inner layers of the retina, have been measured and published (22-26). To the best of our knowledge, no study has been performed to investigate choroidal thickness after YAG capsulotomy. Our purpose here was to reveal whether there is a subclinical change. The causes of retinal complications observed post-YAG capsulotomy, particularly of CME, are commonly revealed as capsular degradation products and a deteriorated blood retinal barrier. Considering the data of our study, no significant choroidal thickness was observed at either 24 or 72 h or at follow-up 3 months after application. Although a slight thickening was observed in the early stages of the process, this thickening had a tendency to diminish over time to the level observed on the first day. A slight rise in thickness particularly in the early days of application could suggest a mild subclinical inflammation (although not statistically significant). Investigating this in detail would necessitate studies with larger sample sizes. The follow-up of changes could be more significant in cases where scanning of macular thickness was made, especially in cases where CME development occurred.

In the analysis of RNFL, a change in average thickness (similar to retinal thickness and volume) was observed with a slight decrease initially in measurements at 4 and 12 weeks; thickness levels reached a thickness level, which was similar to the initial results. The difference between the results were not statistically significant. No significant change in IOP was observed in any case; this circumstance may have a direct effect on the result. Because we have no further data for comparison in this regard, we believe that a comparison with future data would be helpful. If the change in IOP is held more responsible for the alteration in the RNFL level, we believe that conducting this evaluation on cases with IOP changes would be more appropriate.

In our study, after YAG capsulotomy, there was a tendency of slight macular thinning, thinning of RNFL, and thickening of the choroid, and these parameters returned to pre-YAG levels with time. Although not statistically significant, the parameters indicate that the application triggers a mild inflammation. To conclude, YAG capsulotomy is a safe and effective method. However, the smallest dose application and close follow-up would increase the reliability of the application.

\section{REFERENCES}

1. Polak M, Zarnowski T, Zagorski Z. Results of Nd: YAG laser capsulotomy in posterior capsule opacification. Ann Univ Mariae Curie Sklodowska. 2002:57(1):357-63.

2. Billotte C, Berdeaux G. Adverse clinical consequences of neodymium: YAG laser treatment of posterior capsule opacification. J Cataract Refract Surg. 2004:30(10):2064-71.

3. Alimanović-Halilović E. [Complications in the posterior eye segment after Nd-YAG laser capsulotomy]. Med Arh, Bosnian. 2004;58(1):7-9. Bosnian.

4. Ari S, Cingü AK, Sahin A, Çinar Y, Caça I. The effects of Nd: YAG laser posterior capsulotomy on macular thickness, intraocular pressure, and visual acuity. Ophthalmic Surg Lasers Imaging. 2012;43(5):395-400.

5. Eliaçık M, Bayramlar H, Erdur SK, Demirci G, Gülkılık G. Anterior segment optical coherence tomography measurement after neodymium-yttrium-aluminum-garnet laser capsulotomy. Am J Ophthalmol. 2014(158),5:994-8.

6. Karahan E, Tuncer I, Zengin MÖ. The effect of ND: YAG laser posterior capsulotomy size on refraction, intraocular pressure, and macular thickness. J Ophthalmol. 2014; 2014:846385.

7. Spaide RF, Koizumi H, Pozzoni MC. Enhanced depth imaging spectral-domain optical coherence tomography. Am J Ophthalmol. 2008;146(4):496-500.

8. Usui S, Ikuno Y, Akiba M, Maruko I, Sekiryu T, Nishida K, lida T. Circadian changes in subfoveal choroidal thickness and the relationship with circulatory factors in healthy subjects. Invest Ophthalmol Vis Sci.2012;53(4):2300-7.

9. Hooper PL, Rao NA, Smith RE. Cataract extraction in uveitis patients. Surv Ophthalmol. 1990;35(2):120-44.

10. Ionides A, Dowler JG, Hykin PG, Rosen PH, Hamilton AM. Posterior capsule opacification following diabetic extracapsular cataract extraction. Eye (Lond). 1994;8(Pt 5): 535-7.

11. Murrill CA, Stanfield DL, Van Brocklin MD. Capsulotomy. Optom Clin. 1995;4(4):69-83.

12. Findl O, Drexler W, Menapace R, Georgopoulos M, Rainer G, Hitzenberger CK, et al. Changes in intraocular lens position after neodynamium: YAG capsulotomy. J Cataract Refract Surg. 1999;25(5):659-2.

13. Zur D, Fischer N, Tufail A, Mones J, Loewenstein A. Postsurgical cystoid macular edema. Eur J Ophthalmol. 2010:21(1):62-8.

14. Lee MS, Lass JH. Rapid response of cystoid macular edema related to Nd: YAG laser capsulatory to 0.5\% Ketorolac. Ophthalmic Surg Lasers Imaging, 2004;35(2):162-4.

15. Altamirano D, Mermoud A, Pittet N, van Melle G, Herbort CP. Aqueous humor analysis after Nd: YAG laser capsulotomy with the laser flare-cell meter. J Cataract Refract Surg. 1992;18(6):554-8

16. Hougaard JL, Wang M, Sander B, Larsen M. Effects of pseudophakic lens capsule opacification on optical coherence tomography of the macula. Curr Eye Res. 2001; 23(6):415-21.

17. Ruiz-Casas D, Barrancos C, Alio JL, Ruiz-Guerrero M, Muñoz-Negrete FJ. Effect of posterior neodymium:YAG capsulotomy. Safety evaluation of macular foveal thickness, intraocular pressure and endothelial cell loss in pseudophakic patients with posterior capsule opacification. Arch Soc Esp Oftalmol. 2013;88(11):415-22.

18. Minello AA, Prata Jr JA, Mello PA. Efficacy of topic ocular hipotensive agents after posterior capsulotomy. Arq Bras Oftalmol. 2008;71(5):706-10.

19. Lin JC, Katz LJ, Spaeth GL, Klancnik Jr JM. Intraocular pressure control after Nd:YAG laser posterior capsulotomy in eyes with glaucoma. Br J Ophthalmol. 2008;92(3):337-9.

20. Waseem $M$, Khan HA. Association of raised intraocular pressure and its correlation to the energy used with raised versus normal intraocular pressure following Nd:YAG laser posterior capsulotomy in pseudophakes. J Coll Physicians Surg Pak. 2010;20(8): 524-7.

21. Ozkurt YB, Sengor T, Evciman T, Haboğlu M. Refraction, intraocular pressure and anterior chamber depth changes after Nd:YAG laser treatment for posterior capsular opacification in pseudophakic eyes. Clin Exp Optom. 2009;92(5):412-5.

22. Margolis R, Spaide F. A pilot study of enhanced depth imaging optical coherence tomography of the choroid in normal eyes. Am J Opthalmol. 2009;147(5):811-5.

23. Fujiwara A, Shiragami C, Shirakata Y, Manabe S, Izumibata S, Shiraga F. Enhanced depth imaging spectral-domain optical coherence tomography of subfoveal choroidal thickness in normal Japanese eyes. Japn J Ophthalmol. 2012;56(3):230-5.

24. Spaide RF. Age-related choroidal atrophy.Am J Ophthalmol.2009;147(5):801-10.

25. Fujiwara T, Imamura Y, Margolis R, Slakter JS, Spaide RF. Enhanced depth imaging optical coherence tomography of the choroid in highly myopic eyes. American Journal of Ophthalmology.2009;148(3):445-50.

26. Imamura Y, Fujiwara T, Margolis R, Spaide RF. Enhanced depth imaging optical coherence tomography of the choroid in central serous chorioretinopathy. Retina. 2009;29(10):1469-73. 